\title{
Econometric Analysis on the Relationship Between RMB Exchange Rate and Real Estate Price by VAR Model
}

\author{
LIU Ya-chen \\ School of Management \\ Shenyang Jianzhu University \\ Shenyang China \\ lyc@sjzu.edu.cn
}

\author{
ZHANG Shuai \\ School of Management \\ Shenyang Jianzhu University \\ Shenyang China \\ 302623308@qq.com
}

\begin{abstract}
Since the exchange rate reform of China, except for a short-term price fall, the real estate price rose rapidly and reached a record height. This paper chose the monthy data of exchange rate and real estate price from July 2005 to December 2012, and conducts an empirical analysis on the correlation effect of the exchange rate and real estate price by using economic theory, combined with the econometric model. The result showed that there is a positive relationship between them. Now, controlling the foreign capital to enter China due to the RMB appreciation has positive impact on maintaining the stability of China's real estate prices.
\end{abstract}

Keywords-currency exchange rate; real estate price; vector autoregression; econometric analysis

\section{INTRODUCTION}

Since July 21, 2005, we began to implement a new managed floating exchange rate regime which based on the market supply and demand with reference to a basket of currencies.Then the RMB exchange rate became more flexible. Since then, the exchange rate of the RMB against the U.S. got rid of the long-term hovering at 8.27 , started the journey of continuous appreciation. Up to December 2012, the central parity rate of the RMB against the U.S. dollar came to 6.285 , had risen by $28.91 \%$ compared with the beginning of the exchange rate reform.

The appreciation of the RMB increased the expected rate of return on investment assets denominated in RMB, the fame and fortune of the capital to make a lot of hot money flow into China to obtain excess returns. Real estate which has high returns won the favor of international capital for its dual properties as consumer goods and investment goods. With the growing internationalization of the real estate investment behavior, the relationship between housing prices and the exchange rate is bound to be more closely. So , expandding mathematical analysis and empirical test has great significance to this case.

\section{THEORETICAL HyPOTHESES}

The new open economy Macroeconomicss believes that capital market and foreign exchange market have Interactive relationship. External shocks will lead to changes in asset prices conduction through the foreign exchange market. Generally speaking,

The appreciation of the RMB affect housing price mainly through the wealth effect, liquidity effect, the expected effect, spillover effects of credit and expansion effect. Based on this, we propose the following assumptions:

Hypothesis 1: RMB appreciation will cause real estate price increases.

In the case of global excess liquidity and the U.S. dollar continued low interest rates, based on hypothesis 1, increasing housing prices may further attract international speculative capital inflow. In our current management system of exchange rate, international speculative attracted by the high prices further exacerbated by the balance of supply and demand in the foreign exchange market in China, increase the pressure on RMB appreciation.

Hypothesis 2: Increased prices due to the appreciation of the RMB, in turn, it will increase the pressure of RMB appreciation.

In view of China's actual situation, If we expand the fluctuation range of the RMB exchange rate, increase the flexibility of the RMB exchange rate, it will increase the risk premium of international hot money, ease the one-sided appreciation of the RMB and weaken the power of international hot money that flows into China.

Hypothesis 3: Expand the fluctuation range of the RMB exchange rate will reduce the housing price.

\section{SELECTION OF INDICATORS AND MODEL BUILDING}

The paper chose monthly data from July 2005 to December 2012 as the sample range to analysis the relationship between exchange rate reform with real estate prices after exchange rate reform.

RMB appreciation is measured by nominal exchange rate (ER) indicato in directly quotation sheet of the RMB against the U.S. dollar, namely the number of units of U.S. dollars in exchange for $\mathrm{RMB}$, and nationwide real estate prices housing sales price index (HP). The RMB nominal exchange rate (ER) data came from the State Administration of Foreign Exchange website (the www. safe.gov cn), and the national average housing sales price index (HP) data came from the National Bureau of Statistics website (www.stats.gov.cn ). The two sets of data are logarithmic processed to avoid data volatility, which is conducive to eliminate the heteroskedasticity phenomenon exists in time series. In addition, we took the processing of a fixed base ring data on housing sales price index. In this paper, the metering software used is Eviews6.0. 


\section{A. Vector Autoregression Model(VAR)}

VAR model is an unstructured equation model to forecast Interrelated time series and analysis the dynamic impac of random perturbation to the variable system, so as to explain the impact of various economic shocks on economic variables .

The mathematical expression of the $\operatorname{VAR}(\mathrm{p})$ model is:

$\mathrm{Y}_{\mathrm{t}}=\mathrm{A}_{1} \mathrm{y}_{\mathrm{t}-1}+\ldots+\mathrm{A}_{\mathrm{p}} \mathrm{y}_{\mathrm{t}-\mathrm{p}}+\mathrm{Bx}_{\mathrm{t}}+\mathrm{t}=1,2, \ldots, \mathrm{T}$.

Among the equotion, yt is a $\mathrm{k}$-dimensional endogenous variable vector, $\mathrm{xt}$ is a $\mathrm{d}$-dimensional exogenous variable vector, $\mathrm{p}$ is the lag order. $\mathrm{T}$ is the sample number, the $\mathrm{k} \times \mathrm{k}$ dimensional matrix and $\mathrm{k} \times \mathrm{d}$ dimensional matrix $\mathrm{B}$ are coefficient matrix to be estimated. ut is the k-dimensional perturbation vector, there may be contemporaneous correlation between them, but not with its own hysteresis value related and not associated with the right side of equation variables.We assume that $\sum$ is the covariance matrix of ut and it is a $\mathrm{k} \times \mathrm{k}$ positive definite matrix.

\section{B. Impulse Response Function}

The impulse response function describes an endogenous variable changes in a unit from another endogenous variable shock response, the impact generated by the response of the positive and negative direction, adjust the time delay and stable process information. Now take $\operatorname{VAR}(2)$ for example to illustrate the basic idea of the impulse response function:

$\mathrm{X}_{\mathrm{t}}=\mathrm{a}_{1} \mathrm{x}_{\mathrm{t}-1}+\mathrm{a}_{2} \mathrm{x}_{\mathrm{t}-2}+\mathrm{b}_{1} \mathrm{z}_{\mathrm{t}-1}+\mathrm{b}_{2} \mathrm{z}_{\mathrm{t}-2}+\mathrm{u}_{1 \mathrm{t}}$,

$\mathrm{Z}_{\mathrm{t}}=\mathrm{c}_{1} \mathrm{x}_{\mathrm{t}-1}+\mathrm{c}_{2} \mathrm{x}_{\mathrm{t}-2}+\mathrm{d}_{1} \mathrm{z}_{\mathrm{t}-1}+\mathrm{d}_{2} \mathrm{z}_{\mathrm{t}-2}+\mathrm{u}_{2 \mathrm{t}}$,

In the above quotion, $a_{i}, b_{i}, b_{i}, d_{i}$ are parameters, the disturbance term $u_{t}=\left(u_{1 t}, u_{2 t}\right)$, assumed $t$ white noise vector having the following properties: $\mathrm{E}\left(\mathrm{u}_{\mathrm{it}}\right)=0$.

$\operatorname{Var}($ ut $)=E($ ut ut' $)=\sum=($ nij $)$, for $\forall_{t}$;

$\mathrm{E}$ ( uit uis) $=0$, 对于 $\forall \neq \mathrm{t}, \mathrm{i}=1,2$.

Assumes that the above system start from 0 , and let the $\mathrm{x}_{-1}=\mathrm{x}_{-2}=\mathrm{z}_{-1}=\mathrm{z}_{-2}=0, \mathrm{x}_{-1}=\mathrm{x}_{-2}=\mathrm{z}_{-1}=\mathrm{z}_{-2}=0$,

\section{EMPIRICAL TEST}

\section{A. Stationary Test}

When making econometric analysis of time-series data, we must first make stationary test for each variable, otherwise, regressing directly to the non-stationary time series will lead to the spurious regression phenomenon. We conduct unit root to LnER, LnHP with ADF-test method, and the test results are shown in table 1.

TABLE 1 ADF-test of Variable

\begin{tabular}{llccc}
\hline Variable & $\begin{array}{l}\text { Test } \\
(\mathrm{C}, \mathrm{T}, \mathrm{K})\end{array}$ & $\begin{array}{c}\text { ADF } \\
\text { Statistics }\end{array}$ & $1 \%$ Threshold & $\begin{array}{c}\text { Stable or } \\
\text { Not }\end{array}$ \\
\hline LNER & $(\mathrm{C}, \mathrm{T}, 3)$ & -1.235478 & -2.604746 & not \\
$\triangle$ LNER & $(\mathrm{C}, \mathrm{T}, 3)$ & -6.104219 & -2.604746 & yes \\
LnHP & $(\mathrm{C}, \mathrm{T}, 3)$ & -1.536463 & -2.504347 & not \\
$\triangle$ LnHP & $(\mathrm{C}, \mathrm{T}, 3)$ & -4.003821 & -2.604746 & yes \\
\hline
\end{tabular}

Through AIC and SC statistics lag coefficient significanty, we judge the best LNER and LnHP lag period is 3. After making ADF test of heir raw data and the first-order and second-order difference values, we found their second- order difference ADF statistics are less than 1\% significance level threshold, they are stationary time series, are I(2) distribution.

\section{B.Cointegration Test}

The test involves only two variables, so we apply EangleGranger two-step test method. What needs to be emphasized is that in the case of only two variables, EG two-step method is only applicable to the same order integration. While from the above LnER and LnHP the ADF test, we know, LnER and LnHP are I(2), meet the condition that two variables must be in the same order.

First, build the Regression model, use the the method of least squares to estimate long-run equilibrium relationship.

TABLE 2 Regression Results of LnER and LnHP

\begin{tabular}{lcccl}
\hline Variable & Coefficient & Std. NERor & t-Statistic & Prob. \\
\hline LNER & -1.30346 & 0.070422 & -18.50923 & 0 \\
C & 7.377096 & 0.140286 & 52.58603 & 0 \\
$\begin{array}{l}\text { R-squared } \\
\begin{array}{l}\text { Adjusted R- } \\
\text { squared }\end{array}\end{array}$ & 0.844671 & Mean dependent var & 4.782049 \\
\hline
\end{tabular}

As can be seen by the results, they fit good, to $84.47 \%$. the regression equation is:

$\mathrm{LnHP}=7.737-1.303 \mathrm{LnER}+\mu \mathrm{t}$

The second step, estimate residuals smooth. This test can made only on the original residual series test inspection but not on the residual sequence difference. As Inspection formal, select "None", because the alternative equation contains neither time trend nor intercept. Judging through trial and error, and SC and AIC statistics lag coefficient significant, we determined thelag factor as 2 .

TABLE 3 the ADF Test Result of Residuals

\begin{tabular}{lccc}
\hline & t-Statistic & Prob.* \\
\hline Augmented Dickey-Fuller test statistic & -1.922158 & 0.0527 \\
Test critical values: & $1 \%$ level & -2.602794 & \\
& $5 \%$ level & -1.946161 & \\
& $10 \%$ level & -1.613398 & \\
\hline
\end{tabular}

\section{Granger Causality Test}

Granger causality test can only be built on the smooth variable or cointegrated nonstationary variables. From cointegration test above, we know the cointegrated LnER and LnHP can be conducted Granger causality test. The selection of the optimal lag order is based on residual analysis unconstrained with VAR model. According to AIC order determination criteria, we finally determined the optimal lag order $\mathrm{K}=3$. 
TABLE 4 the Result of Granger Causality Test of LnER and LnHP

\begin{tabular}{llll}
\hline Null Hypothesis: & Obs & F-Statistic & Prob.* \\
\hline $\begin{array}{l}\text { LNER does not Granger Cause } \\
\text { LNHP }\end{array}$ & 63 & 1.53869 & 0.2233 \\
$\begin{array}{l}\text { LNHP does not Granger Cause } \\
\text { LNER }\end{array}$ & & 5.69048 & 0.0055 \\
\hline
\end{tabular}

The Probability of that LnER is not LnHP's Granger reason is 0.223 , which shows LnER indeed affect LnHP to a certain extent. While the Probability of LnHP not LnER's Granger reason is 0.005 , far less than 0.05 , indicating that prices rise really driven by the rise in the exchnge rate, and this kinds of effects are more pronounced than the impact of exchange rates on prices. Two-way causal relationship exists between LnER and LnHP.

\section{Impulse Response Function Analysis}

In standard formula of the VAR model, the disturbance is also called the new interest rate, the impulse response function attempts to describe how any disturbance of a variable affect other variables through the model, ultimately feedback into its own process. Now we use the impulse response function to analysis the relationship between housing prices and exchange rate. The following diagrams is their impulse response graphs. The solid line portion are calculated values, and he dotted line is the confidence bands of response function value plus (or minus) twice the standard deviation. The abscissa indicates the impact effect hysteresis number of months, and the vertical axis represents the respective timing index, the solid line represents the impulse response function.
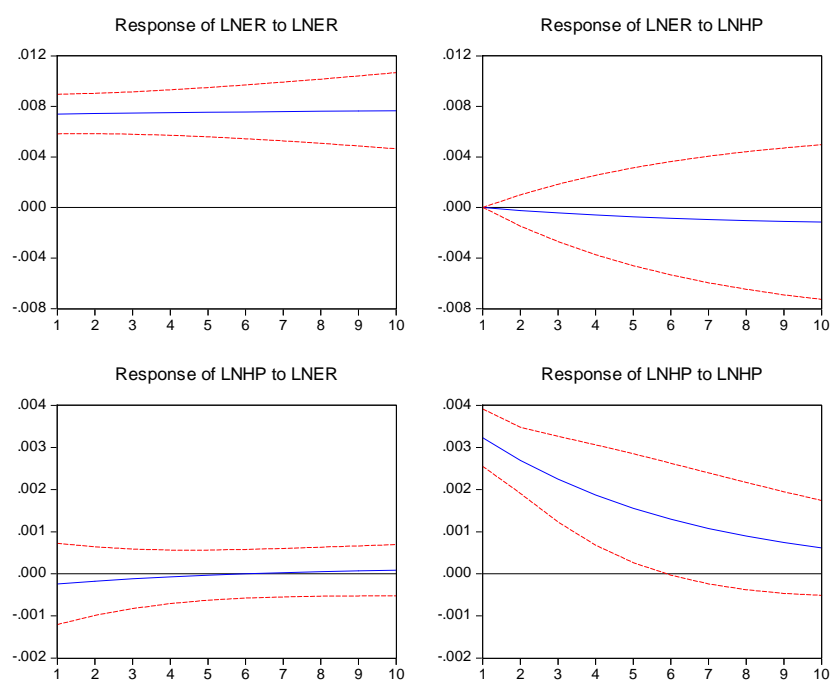

Figure1 Impulse Response Function Analysis Results
For the dynamic response of a unit of standard deviation from the endogenous variables impact: LnER and LnHP have a significant reaction to the impact from theirselves in the current period. Overall, exchange rates and house prices have a negative reaction from the other incremental impact, which prove that there is a long-term interaction mechanism between them.

\section{CONCLUSIONS AND REFLECTIONS}

Drawn through the empirical analysis, and after the exchange rate reform, China's real estate prices and RMB nominal exchange rate have a long-term stable cointegration relationship, which is a positive correlation. The expected appreciation of RMB promoted the rise of real estate prices, and the continuous rise of domestic housing prices attracted global speculative capital to chase for which accelerated the momentum of rising house prices.

The exchange rate is the external price of the national currency, and the real estate industry has become a pillar industry in our country. In the context of globalization, it is necessary to ensure the independence of monetary policy, but also to prevent the international hot money speculation in China's real estate market. In a long run, the most central conduction mechanism between the appreciation of RMB and real estate prices is the foreign exchange regime. Therefore we should continue to improve the exchange rate regime reform gradually, and make it toward equilibrium. thereby establish a flexible exchange rate system.

\section{REFERENCES}

[1] Du Min-jie,Liu Xia-hui. RMB appreciation expectations and changes in real estate prices[J]. World Economy, 2007 , (1):81 - 88.

[2] Gao Bo. The impact of exchange rate and the evolution of real estate bubble: International experience and China's policy orientation[J]. Economic Theory and Economic Management, 2009, (7) :38 -43.

[3] Wang Ai-jian. he relevance of the RMB exchange rate and real estate prices[J]. Financial Research, 2007 , (6) :13 - 22.

[4] Gao Bo,Wang Hui-long. The growth of China's real estate market in transformation: :1978 2008[M] .Bei Jing: Economic Science Press,2009.

[5] Benson E D ,Hansen J L. Canadian/ U. S . Exchange Rates and Nonresident Investors :Their Influence on Residential Property Values[J ] . Journal of Real Estate Research ,2010, (18):433 - 463.

[6] Dichey D A ,Fuller W. A Likelihood Ratio Statistics for Autoregressive Time Series with a Unit Root[J]. Econometrica ,2008, (49) : 1057 - 1072.

[7] Granger C W ,ERwbold P. Spurious Regressions in Econometrics[J] . Journal of Econometrics ,2010, (2) :111 - 120.

[8] Hau H ,Rey H. Exchange Rate, Equity Prices and Capital Flows[Z] . NBER Working Paper $9398,2009$.

[9] Miller N G,Michael A S ,Nicholas O. JapaERse Purchases ,Exchange Rates, and Speculation in Residential Real Estate Markets[J] .Journal of Real Estate Research ,1988, (3):39 - 49.

[10] Stock J H ,Waston M W. A Simple MLE of Cointegrating Vectors in Higher Order Integrated Systems[Z] . NBER Working Paper0083, 1989 .

[11] Granger C W J. Some recent development in a concept of causality [J ]. Jou rnal of Econometrics, 1988, 39: 199- 211.

[12] Engle R F, Granger C W J. Cointegration and errorcorrection: Representation, estimation and testing [J].Econom etrica, 1987, 55: 251-276. 